\title{
Phytoprotection
}

\section{The Safe Use of Fungi for Biological Control of Weeds}

\section{Harry C. Evans}

Volume 79, numéro 4, 1998

OECD Workshop - Sustainable Pest Management, Safe Utilization of New Organisms in Biological Control. Montréal, Québec, Canada. September 27-30, 1998.

Atelier de l'OCDE - Gestion durable des ennemis des cultures,

Utilisation sécuritaire de nouveaux organismes de lutte biologique.

Montréal, Québec, Canada. 27-30 Septembre 1998.

URI : https://id.erudit.org/iderudit/706160ar

DOI : https://doi.org/10.7202/706160ar

Aller au sommaire du numéro

Éditeur(s)

Société de protection des plantes du Québec (SPPQ)l

ISSN

0031-9511 (imprimé)

1710-1603 (numérique)

Découvrir la revue

Citer cet article

Evans, H. C. (1998). The Safe Use of Fungi for Biological Control of Weeds.

Phytoprotection, 79(4), 67-74. https://doi.org/10.7202/706160ar d'utilisation que vous pouvez consulter en ligne.

https://apropos.erudit.org/fr/usagers/politique-dutilisation/ 


\title{
The Safe Use of Fungi for Biological Control of Weeds
}

\author{
Harry C. Evans \\ CABI Bioscience, UK Centre (Ascot), Silwood Park, Ascot, Berks. SL5 TTA, UK.
}

Biological control of weeds using fungal pathogens is a relatively new management strategy and, therefore, risk analysis and safety issues can be said to be still on a learning curve. Two broad approaches are distinguished : classical biological control for exotic or alien weeds, involving the introduction and release of coevolved pathogens from the centre of origin of the target weeds; inundative control for use against endemic weeds, involving the mass production and application of indigenous pathogens as formulated products (mycoherbicides).

\section{CLASSICAL BIOLOGICAL CONTROL}

The deliberate introduction of any alien organism into an ecosystem involves a certain degree of uncertainty, and hence risk, since nature is rarely entirely predictable. Thus, classical biological control has to be subjected to a rigorous, scientifically-based risk analysis before an exotic can be released. In the case of fungal pathogens for the biological control of weeds, these risks have often been considered to be unacceptable, based not on scientific evidence, but on emotive and historical associations with plant disease epidemics. Perhaps this is not surprising given the fact that many of the major food and commodity crops have been decimated in the past by coevolved fungal pathogens which have caught up with their hosts in exotic situations often with catastrophic socio-economic consequences (Large, 1940). Indirectly, however, such infa- mous examples from agriculture demonstrate just how effective natural enemies can be, spreading rapidly and efficiently within and between host populations and impacting severely on their productivity. Ironically, the very fact that rigid host specificity has been maintained provides circumstantial evidence to prove that similar coevolved pathogens of weeds are inherently safe and will not expand their host ranges when introduced into exotic environments. This stability of natural enemies has been emphasised recently by Myers (1996), whilst Marohasy (1996) critically analysed the case histories of insect biocontrol agents implicated in "host shifts". From the latter study, it was concluded that, although more than 600 insect species have been transferred between geographic regions for the biological control of weeds, there have been surprisingly few documented cases of expansion of host range. Furthermore, all of these were predictable behavioural responses and not the result of genetically-based changes. The use of the term "host shift", therefore, was considered to be inappropriate, and the evolutionary theory, which presupposes that non-target plants are at risk from unstable or evolving natural enemies, and logically, that classical biological control is inherently unsafe, was challenged (Marohasy, 1996). Indeed, one important advantage of biological control over chemical control strategies is now considered to be its evolutionary stability: in a coevolved association, the natural enemy adapts to genetic changes in the host but to genetically stable outside of this association. Thus, in 
contrast to chemical pesticides, which have been described as "evolutionary evanescent" due to problems of weed resistance (Holt \& Hochberg, 1997), hostnatural enemy interactions are probably permanent, and, therefore, sustainable.

Nevertheless, relatively few countries have exploited the use of natural enemies, and especially of fungal pathogens, for biological control of exotic weeds. As McFadyen (1998) observed, despite improved techniques for risk analysis and a good track record, with some notable and even spectacular successes, opposition to the introduction of biocontrol agents appears to be increasing (Howarth, 1991; Simberloff \& Stiling, 1996). Indeed, McFadyen (1998) made an eloquent plea, stressing that unnecessary-necessary and ever increasing bureaucracy and red tape should not be allowed to discourage or disrupt classical biological control initiatives which, for many alien weed problems, offer ".... the only safe, practical and economically feasible method that is sustainable in the long term". The inherent safety of this approach for the management of the burgeoning invasive weed problem was highlighted by the fact that, after more than 100 years of experience, only eight examples of damage to non-target plants have been reported, five of which had been anticipated and none resulted in serious economic or environmental damage. These all involved insect agents but it can be safely assumed that if a pathogen had been implicated then the recriminations would have been far more severe.

How are the risks reduced and can potential catastrophes be averted? Host specificity tests provide the essential information on which to base the risk assessment, and thus play the central role in any classical biological control project. The protocol involved in the screening of fungal pathogens has been adapted from the centrifugal, phylogenetic method devised by Wapshere $(1974,1975)$ to evaluate potential insect agents. This involves greenhouse screening of the selected biocontrol agent against a range of plant species, starting with those most closely related to the target weed and progressing to more and more distantly related taxa. As an in-built safeguard, to satisfy local farmers and the public in general, additional test species representing regionally important crop and amenity plants are also included in the final test list. Indeed, the initial protocol proved to be so stringent that modifications in the testing sequence were proposed in order to reduce the chances of rejecting potentially useful agents (Wapshere, 1989). However, as pointed out by Evans \& Ellison (1990) and Evans (1995), the safety requirements, and hence the costs of screening fungal pathogens are consistently more complicated than those for insect agents. For example, specificity testing of insect natural enemies of parthenium weed (Parthenium hysterophorus L.) was limited to less than 70 plant species, whilst for pathogens, more than 120 species, and 17 sunflower cultivars, were included in the screens (Evans, 1995).

Ironically, some of the pioneering, and still the most successful weed pathology programmes were completed before the specificity screening protocol was fully in place. In the oft-quoted example of skeleton weed (Chondrilla juncea L.), 56 plant species were screened against Puccinia chondrillinae Bubak \& Sydow in the Mediterranean centre of origin of the host-pathogen, before the rust was released in Australia. Within a relatively short period of time, weed infestations had been reduced by $99 \%$ to a density approaching that recorded in Europe (Cullen \& Hasan, 1988), with an estimated annual saving of over US\$12 millions resulting from increased crop yields and reduced herbicide usage (Mortensen, 1986). Control has proven to be sustainable and the pathogen so specific that previously unknown but non-rusted biotypes of skeleton weed were identified within the susceptible population. In the case of mistflower, Ageratina riparia (Regel) K. \& R., the white smut (Entyloma ageratinae Barreto \& Evans) was introduced from Jamaica into Hawaii in the early 1970s after screening against a relatively short and disparate host test list and, perhaps more contentiously, 
with only rudimentary knowledge of its taxonomy and true origin (Barreto \& Evans, 1988). Such basic information is now a necessary prerequisite before host range screening can even be initiated.

Some recent projects undertaken by $\mathrm{CABI}$ Bioscience can serve as examples of the problems encountered in host specificity testing of exotic pathogens and the risk analysis involved. Screening of the rust, Puccinia abrupta Diet $\&$ Holw. var. partheniicola (Jackson) Parmelee, a potential biocontrol agent of Parthenium hysterophorus from Mexico, resulted in the development of a strong hypersensitive reaction on several sunflower cultivars. Since this is an important crop in the target area (Queensland), the assessment panel in Australia, made up of quarantine personnel and state scientists, decided that the rust should be screened against these cultivars under extremes of climate, on the assumption that the stressed plants may become susceptible to the pathogen. Fortunately, no further symptoms developed, but these supplementary tests added an extra year to the project, delaying release of the rust in Australia (Parker et al., 1994). An even more problematic case concerned the rust Maravalia cryptostegiae (Cummins) Ono and its rubber-vine host, Cryptostegia grandiflora Roxb. ex R. Br. (Asclepiadaceae), from Madagascar; which is a major invasive weed in Queensland, Australia. After screening of over 70 tests species with no adverse results, a newly described species of the Australian Asclepiadaceae, Cryptolepis grayi Forster, was received for inclusion in the screens. Low levels of rust inoculum failed to induce symptoms on this species but, at saturation levels, several of the test plants developed symptoms of infection with the formation of fertile rust pustules (Evans \& Tomley, 1994). Despite the fact that the sori developed much more slowly and were significantly smaller and fewer in number than on the rubber-vine weed, there was still cause for concern. However, in addition to a macroscopic assessment, screened test plants are also routinely examined microscopically, using a clear staining technique
(Bruzesse \& Hasan, 1983), and, thus, additional evidence to show that resistance mechanisms were in operation could be presented to the decision makers in Australia. The consortium of state quarantine committees voted to approve release of the rust, concluding that the threat posed by the weed to biodiversity in the region, as well as to agricultural activities, far outweighed the risks to a single native species. It was also argued that $C$. grayi is a rare plant in a threatened habitat, geographically isolated from rubber-vine infested areas and environmentally unsuitable for the rust (Evans \& Fleureau, 1993), and, moreover, that it is probably not a natural field host but becomes predisposed to infection in greenhouse tests due to a combination of optimum infection conditions and unrealistic inoculum levels. Wind tunnel experiments to simulate field infection, have since supported this hypothesis (Evans \& Tomley, 1996). A similar prediction of the low risks posed to native susceptible Heliotropium spp. by the European rust, Uromyces heliotropii Sredinski was made by Hasan \& Delfosse (1995). Again, permission was granted by the Australian quarantine and wildlife officials, following peer review, to introduce the rust for control of the exotic weed Heliotropium europeaum L.

Bruckart et al. (1996) re-emphasised the problems with and frequent ambiguous ("equivocal") results from controlled greenhouse screens with symptoms developing on non-target species, and described a novel approach now used in the USA to further evaluate the risks of using classical biological control agents which produce "equivocal" results in host range tests. In this analysis, field data on the behaviour of indigenous plant pathogens is included to predict that of the exotic agent. In one case study, when a strain of Puccinia carduorum Jacky from Turkey, being evaluated for control of musk thistle in the USA induced symptoms on globe artichoke, comparisons were made with an endemic strain of the same rust species which attacks slenderflower thistle in California. Despite the fact that globe artichoke is grown widely in this region, the rust has never been 
reported on it, nor, indeed, are there records of this or any other rust associated with artichoke in Europe, where this crop and rusted musk thistle are sympatric. Thus, it was concluded that the exotic rust strain had a strong "preference" for musk thistle and that even if it infected artichoke in the field then damage would be minimal and hence the risk acceptable. Subsequent field trials in the USA, in which globe artichokes amongst other potential hosts were grown amongst heavily rusted musk thistle plots, supported this interpretation since, over a three-year period, only a single rust pustule was detected on the crop plant (Baudoin et al., 1993). Approval for this "limited" field test was given by APHIS (USDA Animal and Plant Health Inspection Service), based on accepted guidelines (Klingman \& Coulson, 1982), and on the assumption that, if the results showed the pathogen to be a high risk factor, then it could be eradicated. Even though the experimental site was selected in a low musk thistle area, to try to eradicate an exotic organism once released into a new ecosystem, particularly a highly mobile rust fungus, would be unrealistic and somewhat naive. Greathead (1995) concluded from field experience of invasives that eradication is seldom feasible, whilst McFadyen (1998) stated categorically that, "Classical biocontrol is irreversible - an agent once widely established in a new country cannot be eradicated..."

A final part in the risk analysis equation concerns not the potential threat posed by the alien biocontrol agent to non-target plants but, ironically perhaps, to the weed populations themselves in those situations where the plant has economic or ecological benefits to the local populace or fauna. Such conflicts of interests with the weed Paterson's curse or Salvation Jane (Echium plantagineum L.) in Australia led to the most contentious dispute in the history of biological control and resulted in the Biological Control Act of 1984 which provided, for the first time, a legal basis for the introduction of biocontrol agents (Cullen \& Delfosse, 1985).

\section{INUNDATIVE BIOLOGICAL CONTROL (MYCOHERBICIDES)}

Since one of the initial requirements for a successful mycoherbicide was considered to be that the fungal agent had to be a target-specific (indigenous) pathogen, the risks involved to nontarget species were regarded as minimal (Daniel et al., 1973). Nevertheless, because there was no existing protocol for the use of biologicals at the time, “....industry would not consider commercialisation without guidelines for registration" (Templeton, 1992). The latter author details the steps taken to assure safety and promote public acceptance of Collego, one of the first registered mycoherbicides, for control of northern jointvetch (Aeschynomene virginica (L) B.S.P.) in the southern USA, and based on Colletotrichum gloeosporioides (Penz.) Sacc. f. sp. aeschynomene. During this pioneering study, close collaboration was maintained with the U.S. Environmental Protection Agency (EPA), which later led to the publication of guidelines for the registration of mycoherbicides, and of biorationals in general. Templeton (1992) noted that these were less complicated than those initially required for the registration of Collego, a process which took 13 years, and argued that these should be further simplified, particularly relating to toxicology and environmental fate, in order to reduce the considerable registration costs, and thus promote interest in and development of mycoherbicides. He further argued that, although stringent regulations were essential at the time, in order to avoid any negative impacts which would have dealt a body blow to biocontrol programmes in general, twenty years of field experience with the pioneering commercial products, as well as with over 100 experimental products, had shown them to be environmentally safe, genetically stable and with high public acceptance. However, Collego was later discovered to be non-host specific following additional greenhouse and field testing involving a disparate range 
of leguminous genera. Crop species in the genera Lathyrus, Lupinus, Vicia and Pisum were found to be mildly or moderately susceptible to Colletotrichum gloeosporioides f.sp. aeschynomene (TeBeest, 1988). Nevertheless, this was considered an acceptable risk, and did not affect product development and subsequent commercialisation, since Collego is targeted exclusively for use in rice cultivation far removed from susceptible leguminous crops.

A similar extension of host range was later shown by $C$. gloeosporioides. f. sp. malvae, registered as BioMal in Canada for control of round-leaved mallow (Malva pusilla Sm.). In this case, registration was only approved after it had been demonstrated after extensive field testing, that the risk to susceptible crops (safflower) was acceptable (Greaves, 1996). Significantly, in the light of recent developments, the strain of Phytophthora palmivora used in DeVine, one of the first mycoherbicides, was known to attack cucurbitaceous crops, such as melon, but, since the product was designed for use in orchard crops, particularly citrus, it was assessed to be safe if not applied within a specified distance of annual crops (Ridings, 1986; Kenney, 1986). Such selective, site-specific application was based on the knowledge that genera, such as Phytophthora and Colletotrichum, have relatively inefficient dissemination mechanisms, and thus would not pose a threat to non-target crops if these were grown outside of the pathogen's known maximum dispersal range. Instructions to this effect would, of course, be included on the product label. The development of DeVine was a pioneering venture in more ways than one, since it also demonstrated the feasibility of exploiting virulent crop pathogens for weed control. Patently, their use necessitates prior in-depth epidemiological studies before risk analyses can be made. Such a comprehensive investigation was undertaken in the Netherlands to assess the risks involved in using the silverleaf fungus, Chondrostereum purpureum (Pers. : Fr.) Pouzar, for control of black cherry, Prunus serotina Ehrh.; a North American species which is now an invasive weed in pine plantations and a threat to native trees (de Jong et al., 1990). This is also a well-known pathogen of commercial Prunus spp., including cultivated cherry, plum and ornamentals. A conceptual and later a simulation model were developed, based on epidemiology, micrometeorology and air

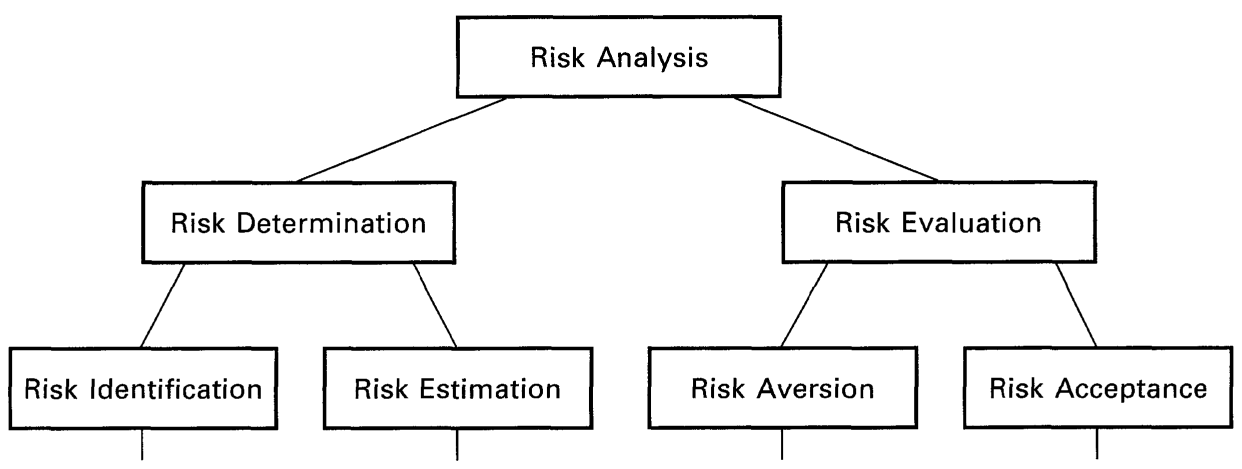

Threat to non-target Probability of and plants. extent of damage to non-targets (e.g. value of crop loss.)
Reduction or avoidance (e.g. developing mutant strains by genetic manipulation; changing farming practices.)
"Risk referees" (e.g. quarantine or state authorities, farmers, conservationists.)

Figure 1. Components of a risk analysis (adapted from de Jong et al., 1990) 
pollution data, in order to predict the risks posed by artificially-increased populations of the pathogen to nontarget hosts. Inoculation experiments using mycelial preparations, were also used to supplement these models. It was found that the risk to non-targets is high up to $500 \mathrm{~m}$ from the treated area but negligible at $5,000 \mathrm{~m}$. Subsequently, the Dutch Plant Protection Service confirmed that the use of $C$. purpureum for control of $P$. serotina was acceptable, except in those situations where the site to be treated was within $500 \mathrm{~m}$ of commercial fruit-growing. A mycoherbicide, Biochon, is currently under development. Figure 1 shows the components of risk analysis identified and defined during the study (de Jong et al., 1990). The use of this pathogen to control weeds deciduous trees in conifer plantations is also being contemplated in Canada (Prasad, 1994).

\section{DICUSSION}

The over-riding concern, to both regulatory authorities and to the public in general, in using fungal pathogens for control of weeds, is their potential threat to non-target plants. This is especially relevant to classical biological control where exotic pathogens are introduced into new ecosystems. The International Union for Conservation of Nature and Nature Resources (IUCN) issued a position statement relating to the translocation of living organisms in order to avoid the potential disastrous consequences of poorly planned (i.e. non scientific) introductions and to aid decision making (IUCN, 1987). Guidelines were given for intentional or bene- ficial introductions in which it is stated that "No alien species should be deliberately introduced into any natural habitat....", which, if interpreted correctly, would preclude classical biological control for the management of many invasive weeds. The essential steps in planning an introduction were detailed, including an assessment phase culminating in a decision on the desirability of the introduction, based on "a risk-and threat analysis". This was recently followed-up by a code of conduct for the import and release of exotic biological control agents (FAO, 1996), with one of the main objectives of promoting the safe use of biocontrol agents. Amongst the main responsibilities of the importer should be the preparation of a dossier on the agent which identifies potential hazards and analyses the risks involved; the relevant authorities can use this dossier to undertake a pest risk analysis, whereby risks for non-target organisms are assessed and risk-mitigating procedures are identified. Thus, scientific guidelines are now in place to ensure the safety of classical biological control agents. However, it should be stressed that all the fungal pathogens released so far into exotic environments have undergone some form of scientific risk analysis because, as Cook et al. (1996) state: "It is axiomatic that no responsible scientist involved in the development and implementation of microbial biocontrol would deliberately introduce.... a microorganisms with known potential for an unmanageable adverse effect....". Central to the risk analysis is host range testing and the phylogenetic or macroevolutionary approach currently in use is considered to be an extremely useful tool in risk assessment (Weidemann, 1991; McClay, 1996). However, these authors also proposed that a microevolutionary or genetic assessment should also be made to determine any genetic variability in the host-pathogen associations and hence the risks of host shifts, but, since this will add considerably to the costs involved and delay introductions, is it necessary? In contrast, risk analysis of indigenous fungal pathogens applied for inundative control is now based more on epidemiological studies, rather than as critical host range testing, particularly since more plurivorous pathogens are being evaluated.

\section{REFERENCES}

Barreto, R.W. \& Evans, H.C. (1988). Taxonomy of a fungus introduced into Hawaii for biological control of Ageratina riparia (Eupatonae: Compositae), with observations on related weed pathogens. Transactions of the British Mycological Society 91, 81-97. 
Baudoin, A.B., Abad, R.G., Kok, L.T. \& Bruckart, W.L. (1993). Field evaluation of Puccinia carduorum for biological control of must thistle. Biological Control 3, 53-60.

Bruckart, W.L., Supkoff, D.M. \& Yang, S.M. (1996). Indigenous plant pathogens in evaluations of foreign biological control candidates in the United States of America. In: Proceedings, Ninth International Symposium on Biological Control of Weeds (eds. V.C. Moran \& J.H. Hoffmann), pp. 71-77. University of Cape Town : South Africa.

Bruzesse, E. \& Hasan, S. (1983). A whole leaf clearing and staining technique for host specificity studies of rust fungi. Plant Pathology 32, 335-338.

Cook, R.J., Bruckart, W.L., Coulson, J.R., Goettel, M.S., Humber, R.A., Lumsden, R.D., Maddox, J.V., McManus, M.L., Moose, L., Meyer, S.F., Quimby, P.C., Stack, J.P. \& Vaughn, J.L. (1996). Safety of microorganisms intended for pest and plant disease control: a framework for scientific evaluation. Biological Control 7, 333-351.

Cullen, J.M. \& Delfosse, E.S. (1985). Echium plantagineum: catalyst for conflict and change in Australia. In: Proceedings, Sixth International Symposium on Biological Control of Weeds (ed. E.S. Delfosse), pp. 249-292. Agriculture Canada: Ottawa.

Cullen, J.M. \& Hasan, S. (1988). Pathogens for the control of weeds. Philosophical Transactions of the Royal Society of London 318: 213-224.

Daniel, J.T., Templeton, G.E., Smith, R.J. \& Fox, W.T. (1973). Biological control of northern jointvetch in rice with an endemic fungal disease. Weed Science 21, 303-307.

De Jong, M.D., Scheepens, P.C. \& Zadoks, J.C. (1990). Risk analysis for biological control: a Dutch case study in biocontrol of Prunus serotina by the fungus Chondrostereum purpureum. Plant Disease 74, 189-194.

Evans, H.C. (1995). Pathogen-weed relationships: the practice and problems of host range screening. In: Proceedings, Eighth International Symposium on Biological Control of Weeds (eds. E.S. Delfosse \& P.R. Scott), pp. 539-551. DSIR/CSIRO: Melbourne, Australia.

Evans, H.C. \& Ellison, C.A. (1990). Classical biological control of weeds with microorganisms : past, present, prospects. Aspects of Applied Biology 24, 39-49.

Evans, H.C. \& Fleureau, L. (1993). Studies on the rust, Maravalia cryptostegiae, a potential biological control agent of rubber-vine weed, Cryptostegia grandiflora
(Asclepiadaceae: Periplocoideae), in Australia. II infection. Mycopathologia 124, 175-184.

Evans, H.C. \& Tomley, A.J. (1994). Studies on the rust, Maravalia cryptostegiae, a potential biological control agent of rubber-vine weed, Cryptostegia grandiflora (Asclepladaceae : Periplocoideae), in Australia. III host range. Mycopathologia 126, 93-108.

Evans, H.C. \& Tomley, A.J. (1996). Greenhouse and field evaluations of the rubber vine rust, Maravalia cryptostegiae, on Madagascan and Australian Asclepiadaceae. In: Proceedings, Ninth International Symposium on Biological Control of Weeds (eds. V.C. Moran \& J.H. Hoffmann), pp. 165-169. University of Cape Town : South Africa.

FAO (1996). International Standards for Phytosanitary Measures. Secretariat of the International Plant Protection Convention : Rome, Italy.

Greathead, D. J. (1995). Benefits and risks of classical biological control. In: Biological Control : Benefits and Risks. (eds. H. M. T. Hokkanen \& J. M. Lynch), pp. 53-63. Cambridge University Press.

Greaves, M.P. (1996). Microbial herbicides factors in development. In: Crop Protection Agents from Nature (ed. L.G. Copping), pp. 444-467. Royal Society of Chemistry: Cambridge, UK.

Hasan, S. \& Delfosse, E.S. (1995). Susceptibility of the Australian native, Heliotropium crispatum, to the rust fungus Uromyces heliotropii, introduced to control common heliotrope, Heliotropium europaeum. Biocontrol Science \& Technology 5, 165-174.

Holt, R.D. \& Hochberg, M.E. (1997). When is biological control evolutionary stable (or is it)? Ecology 78, 1673-1683.

Howarth, F.G. (1991). Environmental impacts of classical biological control. Annual Review of Entomology 36, 485-509.

IUCN (1987). Translocation of Living Organisms. IUCN: Gland, Switzerland.

Kenney, D.S. (1986). DeVine - the way it was developed - an industrialist's view. Weed Science 34, 15-16.

Klingman, D.L. \& Coulson, J.R. (1982). Guidelines for introducing foreign organisms into the U.S. for biological control of weeds. Plant Disease 66, 1205-1209.

Large, E.C. (1940). The Advance of the Fungi. J. Cape : London.

Marohasy, J. (1996). Host shifts in biological weed control: real problems, semantic difficulties or poor science? International Journal of Pest Management 42, 71-75. 
McClay, A.S. (1996). Host range, specificity and recruitment. In: Proceedings, Ninth International Symposium on Biological Control of Weeds (eds. V.C. Moran \& J.H. Hoffmann), pp. 105-112. University of Cape Town : South Africa.

McFadyen, R.E.C. (1998). Biological control of weeds. Annual Review of Entomology 43, 369-393.

Mortensen, K. (1986). Biological control of weeds with plant pathogens. Canadian Journal of Plant Pathology 8, 229-231.

Myers, J.H. (1996). Adaptation of biological control agents: should we be worried? In: Proceedings, Ninth International Symposium on Biological Control of Weeds (eds. V.C. Moran \& J.H. Hoffman), p. 102. University of Cape Town : South Africa.

Parker, A., Koklen, A.N.G. \& Tomley, A.J. (1994). Host specificity testing and assessment of the pathogenicity of the rust, Puccinia abrupta var. partheniicola, as a biological control agent of parthenium weed (Parthenium hysterophorus). Plant Pathology 43, 1-16.

Prasad, R. (1994). Influence of several pesticides and adjuvants on Chondrostereum purpureum - a bioherbicide agent for control of forest weeds. Weed Technology 8, 445-449.

Ridings, W.H. (1986). Biological control of stranglervine in citrus - a researcher's view. Weed Science 34, 31-32.

Simberloff, D. \& Stiling, P. (1996). How risky is biological control? Ecology 77, 19651974.
TeBeest, D. O. (1988). Additions to the host range of Colletotrichum gloeosporioides f. sp. aeschynomere. Plant Disease 72, 16-18.

Templeton, G.E. (1992). Regulatory encouragement of biological weed control with plant pathogens. In: Regulations and Guidelines: Critial Issues in Biological Control (eds. R. Charudattan \& H.W. Browning), pp. 61-63. Institute of Food \& Agricultural Sciences : University of Florida, Gainesville.

Teng, P.S. \& Yang, X.B. (1993). Biological impact and risk assessment in plant pathology. Annual Review of Phytopathology 31, 495-521.

Wapshere, A.J. (1974). A strategy for evaluating the safety of organisms for biological weed control. Annals of Applied Biology 77, 201-211.

Wapshere, A.J. (1975). A protocol for programmes for biological control of weeds. PANS 21, 295-303.

Wapshere, A.J. (1989). A testing sequence for reducing rejection of potential biological control agents for weeds. Annals of Applied Biology 114, 515-526.

Weidemann, G.J. (1991). Host-range testing: safety and science. In: Microbial Control of Weeds (ed. T.O. TeBeest), pp. 83-96. Chapman \& Hall : New York. 